\title{
INVESTIGATION OF THE SUGAR CONTENT OF URINE FROM NORMAL SUBJECTS AND PATIENTS WITH RENAL AND HEPATIC DISEASE BY PAPER CHROMATOGRAPHY
}

\author{
BY \\ G. H. APTHORP \\ From the Children's Department, St. Bartholomew's Hospital, London
}

(RECEIVED FOR PLBLICATION FEBRUARY 6, 1956)

Pavy and Siau in 1901 showed that normal urine contained small amounts of glucose, and other sugars which they were unable to identify by the osazone technique. Little interest has been shown in the sugar content of urine except in the case of glucose, and no data are available defining the normal values for the small amounts of other sugars in normal urine.

Partridge in 1946 applied the technique of filter paper chromatography to the identification of sugars. This technique allows the simultaneous identification and estimation of a mixture of closely related sugars. More recently the method has been applied to the study of urinary lactose output in pregnancy by Flynn, Harper, and de Mayo (1953), and to the study of sucrosuria in children by Moncrieff and Wilkinson (1954).

The main purpose of the work described in this paper was to define the normal values for the various sugars which occur in urine. In addition the results of the examination of urine from a small number of patients with renal and liver disease are described, as it is felt they may be of interest.

\section{Selection of Material}

Urines were examined from 100 normal children and 27 normal adults. The children were patients admitted for minor acute illnesses, showed no evidence of chronic disease, and were fit for discharge home. The adults were patients admitted to surgical wards for minor surgery. Both fasting morning specimens and specimens of urine obtained after a meal were examined.

\section{Method}

The urines were preserved with thymol fluroride and examined the same day. Salts and amino-acids were removed by shaking the urine with a mixed bed resin, "biodeminrolite." which Woolf (1953) has shown results in no loss of sugar. It was found necessary to apply $0.2 \mathrm{ml}$. of treated urine to the paper in order to obtain a chromatogram suitable for quantitative analysis. This quantity was used throughout the investigation.

The descending method of chromatography was used with butanol-acetic acid-water solvent. The chromatograms were run for 16 hours on a relatively fast paper. namely, Whatman 531. Duplicate sheets were developed with aniline hydrogen phthalate and naphthoresorcinol, as suggested by Woolf (1951). The sugars were identified by known marker sugars run simultaneously, galactose being identified by runs before and after yeast fermentation.

Glucose was estimated by Block, Le Strange, and Zweig's (1952) method. The maximum density of the glucose spot of the urine was measured photoelectrically, and compared with 14 known amounts of glucose ranging from $5 \mu \mathrm{g}$. to $100 \mu \mathrm{g}$. run simultaneously. The other sugars were estimated by direct visual comparison with 14 known amounts of the sugars run simultaneously. The sheets were viewed by transmitted ultra-violet light.

The edges of the xylose and arabinose areas overlapped to some extent without interfering with identification, but may have given somewhat high readings in cases where relatively large amounts of both these sugars were present.

Benedict's (1909) test was carried out on all specimens of urine as suggested by Harrison (1947).

Urine, $0.5 \mathrm{ml}$,, with $5 \mathrm{ml}$. reagent, is placed in a boiling water-bath for five minutes and allowed to cool. The colour of the precipitate is noted.

\section{Results}

To test the accuracy of the method known amounts of sugars were added to normal urine, and the sugar content estimated by the method. Specimens of cerebrospinal fluid were also examined by the method and the results compared 
with those obtained by the method of Folin and $\mathrm{Wu}(1920)$. The method was found to give results accurate to $\pm 20 \%$, and quantities down to 2.5 $\mu \mathrm{g}$. could be identified, except in the cases of fructose and sucrose where $10 \mu \mathrm{g}$. was necessary for identification and estimation. (Using $0.2 \mathrm{ml}$. of urine, $2.5 \mu \mathrm{g}$. of sugar corresponds to $1.25 \mathrm{mg}$. sugar per $100 \mathrm{ml}$. urine.)

Normal Values.-One hundred and sixty-four specimens of urine from 100 normal children and 27 normal adults were examined. Twenty-eight of these specimens were collected after a meal, and the remainder were fasting morning specimens. The results are summarized in Table $I$.

TABLE I

ANALYSIS OF 164 URINES FROM 100 NORMAL CHILDREN AND 27 ADULTS

\begin{tabular}{|c|c|c|c|c|c|}
\hline Sugar & $\begin{array}{c}\text { Age } \\
\text { Group }\end{array}$ & $\begin{array}{l}\text { Number } \\
\text { of } \\
\text { Specimens } \\
\text { Examined }\end{array}$ & $\begin{array}{l}\% \text { Urines } \\
\text { Contain- } \\
\text { ing the } \\
\text { Sugar }\end{array}$ & $\begin{array}{c}\text { Normal } \\
\text { Range } \\
\text { (mg.\%) }\end{array}$ & $\begin{array}{l}\text { Average } \\
\text { Content } \\
\text { (mg.\%) }\end{array}$ \\
\hline $\begin{array}{l}\text { Glucose } \\
\text { Lactose }\end{array}$ & $\begin{array}{l}\text { All ages } \\
0 \text { to } 6 \text { months } \\
6.12 \text { to } 12 \\
\text { years }\end{array}$ & $\begin{array}{r}164 \\
9 \\
123\end{array}$ & $\begin{array}{r}100 \\
100 \\
59\end{array}$ & $\begin{array}{l}1-12 \\
6-120 \\
0-35\end{array}$ & $\begin{array}{c}4 \cdot 3 \\
37 \\
9\end{array}$ \\
\hline Xylose & $\begin{array}{l}\text { Adults } \\
\text { Children } \\
\text { Adults }\end{array}$ & $\begin{array}{r}32 \\
132 \\
32\end{array}$ & $\begin{array}{l}22 \\
70 \\
30\end{array}$ & $\begin{array}{ll}0- & 10 \\
0- & 30 \\
0- & 3\end{array}$ & $\begin{array}{l}7 \\
3 \cdot 6\end{array}$ \\
\hline Arabinose & $\begin{array}{l}\text { Children } \\
\text { Adults } \\
\text { Babies }\end{array}$ & $\begin{array}{r}132 \\
32\end{array}$ & $\begin{array}{l}80 \\
30 \\
45\end{array}$ & $\begin{array}{ll}0- & 15 \\
0- & 3 \\
0 & 20\end{array}$ & $\begin{array}{l}3 \cdot 5 \\
1 \cdot 5\end{array}$ \\
\hline Galactose & $\begin{array}{l}\text { Children } \\
\text { Adults }\end{array}$ & $\begin{array}{r}123 \\
32\end{array}$ & $\begin{array}{l}\mathrm{Nil} \\
\mathrm{Nil}\end{array}$ & $\begin{array}{l}\mathrm{Nil} \\
\mathrm{Nil}\end{array}$ & $\begin{array}{l}\mathrm{Nil} \\
\mathrm{Nil}\end{array}$ \\
\hline Fructose & $\begin{array}{l}\text { Children } \\
\text { Adults }\end{array}$ & $\begin{array}{l}34 \\
14\end{array}$ & $\begin{array}{l}9 \\
7\end{array}$ & $\begin{array}{lr}0- & 15 \\
0- & 5\end{array}$ & 10 \\
\hline Sucrose & $\begin{array}{l}\text { Children } \\
\text { Adults }\end{array}$ & $\begin{array}{l}34 \\
14\end{array}$ & $\begin{array}{r}6 \\
\mathrm{Nil}\end{array}$ & $\stackrel{0-15}{\mathrm{Nil}}$ & $\stackrel{9}{\mathbf{N}}$ il \\
\hline
\end{tabular}

Glucose.-All urines contained some glucose. The range was between $1 \mathrm{mg}$. and $11.5 \mathrm{mg}$. glucose per $100 \mathrm{ml}$. urine, with a mean value of $4.3 \mathrm{mg}$. \% . The distribution of glucose in normal urine is shown in Fig. 1. No difference could be found between the glucose content of urine from children or adults, and the glucose content of the urine was unrelated to the specific gravity of the urine. Urines collected after a meal contained no more glucose than fasting specimens.

Lactose.-This sugar appeared surprisingly often. The amount found was closely related to the intake of milk and varied from day to day in any given case. None of the adults were pregnant or lactating.

Pentose.-Some pentose was found in nearly all urines, either xylose or arabinose, or more commonly both sugars. The larger amounts of pentose were found in urines of high specific gravity, in urines collected after meals, and from normal children on high-protein diets, and during the Christmas festivities. Children's urine contained more pentose than adults.

Galactose.-This sugar was only found in the urine of milk-fed infants in quantities up to 20 mg. per $100 \mathrm{ml}$. urine.

Fructose and Sucrose.-Urines from 48 normal children and adults were examined specifically for these sugars. It was not possible to estimate quantities below $5 \mathrm{mg}$. per $100 \mathrm{ml}$. urine, and in the cases in which these sugars were demonstrated further specimens showed the excretion to be inconstant and presumably related to dietary intake.

Other Sugars. - Apart from the abovementioned seven sugars, no other sugars were found in normal urine. No ribose or xyloketose was found, although both are readily identified chromatographically.

\section{Abnormal Results}

Three hundred and twenty urines were examined from 176 patients with a wide variety of diseases. Eighty-three of these patients were children and

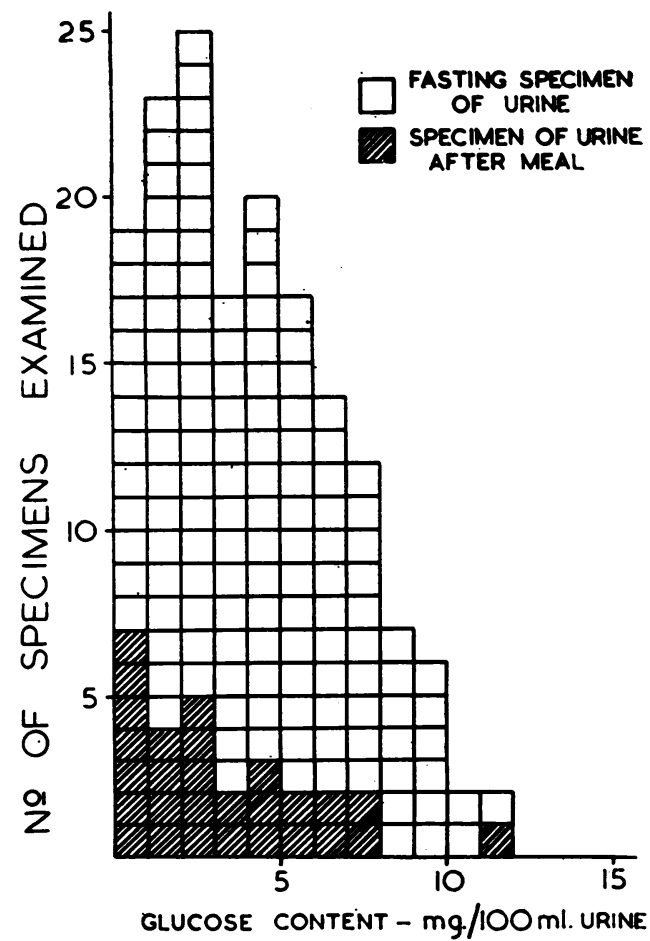

Fig. 1.-Diagram to show the results of analysis of 164 specimens of urine for glucose from 100 normal children and 27 normal adults. Each square represents one specimen of urine. 


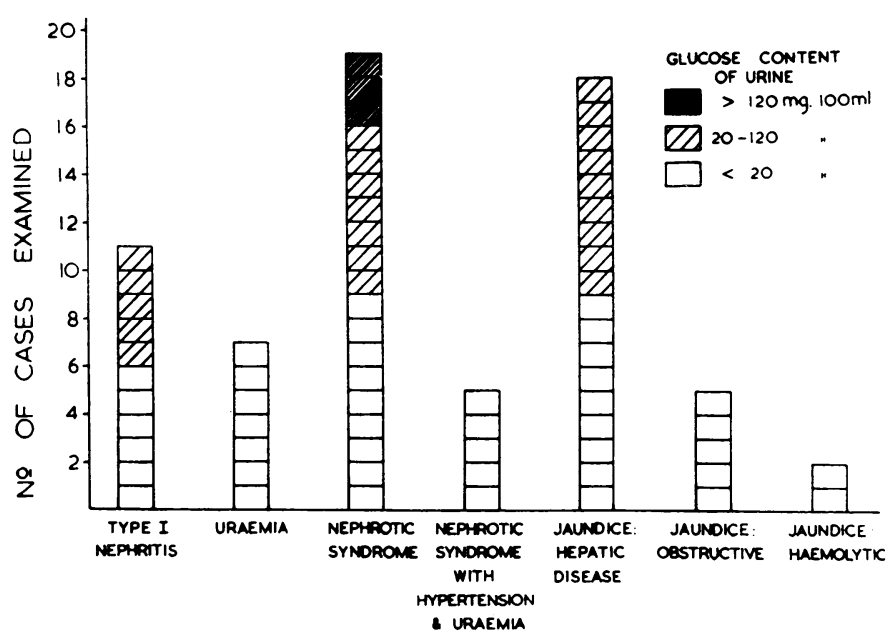

FIG. 2.-Diagram to show incidence of increase in glucose content of urine in patients diagnosed as type 1 nephritis, uraemia due to malignant hypertension and nephrotic syndrome, and in jaundiced patients with hepatic disease, obstructive jaundice, and haemolytic jaundice.

93 adults. All urines were fasting morning specimens. Excluding patients in whom gross glycosuria was to be expected, such as those with diabetes mellitus, Cushing's syndrome, and patients in whom a low renal threshold was demonstrated by glucose tolerance test, only in renal and hepatic disease was the glucose content of the urine found to be increased. Urines from eight children with high pyrexia were examined, but none contained more than $10 \mathrm{mg}$. glucose per $100 \mathrm{ml}$. urine.

Renal Disease.-Fasting specimens of urine from 11 cases of Ellis type 1 nephritis (eight children and three adults) were examined. Five of these 11 cases showed a transient increase in glucose excretion, passing between 20 and $40 \mathrm{mg}$. glucose per $100 \mathrm{ml}$. urine. In all cases the glucose content fell to below $10 \mathrm{mg}$. glucose per $100 \mathrm{ml}$. urine before discharge. The other sugars appeared within normal limits.

Fasting urines from seven adults with uraemia due to malignant hypertension showed a normal sugar content.

Fasting urines from 24 cases of nephrotic syndrome (oedema of renal origin associated with gross albuminuria and low plasma albumin) were examined. Of these 15 were children and nine adults. Three children passed urine containing between 120 and $620 \mathrm{mg}$. glucose per $100 \mathrm{ml}$. urine. Clinically all three children were typ:cal cases of Ellis type 2 nephritis. Seven other cases persistently passed urine containing between 20 and $100 \mathrm{mg}$. glucose per $100 \mathrm{ml}$. urine. In all cases the sugars other than glucose appeared within normal limits for patients on a high-protein diet.

Jaundiced Patients.-Fasting urines from 18 jaundiced patients with clinical and biochemical evidence of liver disease were examined. Nine of these patients showed an increased glucose content in their fasting urines ranging between 20 and $100 \mathrm{mg}$. glucose per $100 \mathrm{ml}$. urine. The other sugars also appeared increased, notably lactose and fructose in adults, and galactose and lactose in children. Five cases of obstructive jaundice and two cases of haemolytic jaundice passed urine containing normal amounts of sugar.

Relationship between Benedict's Test and Sugar Content of Urine.-All 484 specimens of urine in this series were tested with Benedict's reagent. Red and yellow reductions were noted as such. In the case of green reduction, if the precipitate on standing was predominantly grey or green the reaction was called negative. If the precipitate was dull yellow the reaction was considered doubtful. When a green reduction was associated with a bright yellow precipitate the test was called positive.

In assessing the sensitivity of the test it is important to take into account all sugars in the urine. as often the reduction is due to the summation effect of two or more of the commonly occurring sugars. These sugars, of course, vary in their ability to reduce Benedict's reagent. The copperreducing power of the various sugars in a specimen were therefore calculated from Bertrand's (1906) formula, and the total sugar content expressed as the equivalent amount of glucose in mg. per $100 \mathrm{ml}$. urine.

It was found that all urines giving a positive result with the reagent contained sugars equiva- $\sigma$ lent to $50 \mathrm{mg}$. or more of glucose per $100 \mathrm{ml}$., and $\widetilde{O}$ a negative test was always associated with urines $\underset{\mathrm{C}}{\mathrm{N}}$ containing less than $50 \mathrm{mg}$. per $100 \mathrm{ml}$. urine. O Doubtful tests, however, were sometimes associated with increased amounts of sugar, but sometimes the urine contained only the normal trace. insufficient to account for the reduction. Many of the latter were concentrated specimens from children.

\section{Discussion}

As far as the examination of urine from healthy people is concerned, the results show that there is 
an upper limit above which the glucose content of the urine does not rise in health. No urine from healthy people, either fasting or after food, contained more than $12 \mathrm{mg}$. glucose per $100 \mathrm{ml}$. urine. A normal meal produced no significant increase in the glucose content of the urine ; presumably the moderate rise in glucose level in blood and glomerular filtrate is well within the power of the healthy renal tubules to reabsorb glucose. The concentration of the other sugars in the urine appeared to vary with the diet, and in healthy people glucose usually accounted for a small percentage only of the total sugar.

The results in cases of renal disease are based on too few cases to be able to draw any accurate conclusions. Approximately half the cases of Ellis type 1 nephritis showed a transient increase in the glucose content of the urine (20 to $40 \mathrm{mg}$. \%), and just over a third of patients examined with the nephrotic syndrome showed a small but persistent increase in the glucose content of the urine (20 to $100 \mathrm{mg}$. \%). A possible explanation would be that relatively healthy glomeruli are served by tubules which have suffered local damage or impairment of function. The finding of three out of 24 patients with the nephrotic syndrome who passed quite large amounts of glucose in their urine $(120$ to $620 \mathrm{mg}$. \%) is of interest. In all three cases the clinical diagnosis was Ellis type 2 nephritis, and none had any abnormality suggestive of the Fanconi syndrome (Fanconi, 1946). It is possible that renal glycosuria may be more common in organic renal disease than is supposed. The glucose content of the urine was not increased in five nephrotic patients with nitrogen retention or hypertension. No relationship was found between the presence of an increased glucose content of the urine and the response to conservative treatment, cortisone therapy, degree of oedema, or age of the patient.

The finding of increased amounts of sugar in the urine of patients with liver disease might be expected, as the urinary output or blood levels of most of these sugars have been used in assessing hepatic function. The urines from jaundiced patients with hepatic disease which reduced Benedict's reagent were found to contain a mixture of sugars, the summation of which accounted for this reduction. Often glucose was not the dominant sugar, fructose or lactose in adults, and lactose or galactose in young children, accounting in large part for the reduction. The urinary sugar pattern in patients with liver disease varied markedly from day to day and appeared related to diet.
A negative Benedict's reaction appears to be a reliable indication that the sugar content of the urine is equivalent to less than $50 \mathrm{mg}$. glucose per $100 \mathrm{ml}$. urine, and few specimens in this series with a significant increase in any sugar gave a true negative result. The test needs to be carefully carried out and the precipitate examined after standing for the test to be reliable when low concentrations of sugar are present. The usual ward boiling method probably accounts for the few positive results that are noted in cases of the nephrotic syndrome and liver disease

\section{Summary}

Analysis of the sugar content of specimens of urine from 100 normal children and 27 normal adults was carried out and the range of normal values determined.

All urines from normal children and adults contained less than $12 \mathrm{mg}$. glucose per $100 \mathrm{ml}$. urine.

Urines from 176 patients with a variety of diseases were examined. Excluding patients with a gross glycosuria of known cause, only in patients with renal or hepatic disease was the glucose content of the urine found to be above $12 \mathrm{mg}$. per $100 \mathrm{ml}$. urine.

A transient increase in the glucose content of the urine in type 1 nephritis and a persistent increase in the urinary glucose content in some cases of the nephrotic syndrome was observed.

Reduction of Benedict's reagent in jaundiced patients with hepatic disease was found to be due to the summation effect of a mixture of the commonly occurring sugars.

The results of Benedict's test in relation to the sugar content of the urines are discussed.

I wish to acknowledge my debt to Dr. C. F. Harris for encouragement and facilities in his wards, and to Dr. H. E. Archer and Dr. W. G. Dangerfield for advice and help with the technique of chromatography.

\section{REFERENCES}

Benedict, S. R. (1909). J. biol. Chem., 5, 485.

Bertrand, G. (1906). Bull. Soc. chim. Paris, 35, 1285.

Block, R. J., Le Strange, R., and Zweig, G. (1952). Paper Chromatography, p. 45. Academic Press, New York.

Fanconi, G. (1946). Helv. paediat. Acta, 1, 183

Flynn, F. V., Harper, C., and Mayo, P. de (1953). Lancet, 2, 698.

Folin, O., and Wu, H. (1920). J. biol. Chem., 41, 367.

Harrison, G. A. (1947). Chemical Methods in Clinical Medicine, p. 117. J. \& A. Churchill, London.

Moncrieff, A., and Wilkinson, R. H. (1954). Acta paediat. (Uppsala), 43, Suppl. 100 , p. 495.

Partridge, S. M. (1946). Nature (Lond.), 158, 270.

Pavy, F. W., and Siau, R. L. (1901). J. Physiol. (Lond.), 26, 282 . Woolf, L. I. (1951). Gt Ormond Str. J., 1, No. 2, p. 61.

- (1953). Nature (Lond.), 171, 841. 